\title{
Use of Herd Solutions from a Random Regression Test-Day Model for Diagnostic Dairy Herd Management
}

\author{
M. Koivula, ${ }^{\star 1}$ J. I. Nousiainen, † J. Nousiainen,‡ and E. A. Mäntysaari ${ }^{\star}$ \\ *MTT Agrifood Research Finland, Biotechnology and Food Research, Biometrical Genetics, and \\ †MTT Agrifood Research Finland, Animal Production Research, FIN-31600 Jokioinen, Finland \\ $\ddagger$ Valio Ltd./Farm Division, PO Box 10, FIN-00039 Valio, Finland
}

\section{ABSTRACT}

In a random regression test-day model, environmental effects in addition to individual animal factors can be included and analyzed. Moreover, instead of herdyear classification of the management groups, the herdtest-day classification within the model better accounts for month-to-month short-term environmental variation in production and somatic cell count (SCC) traits. The herd management levels of milk yield (milk deviation from whole-country mean, kilograms/day), protein and fat concentration (protein and fat deviation, \%), and SCC (SCC deviation, 1,000 cells $/ \mathrm{mL}$ ) are used in the dairy herd management Web application "Maitoisa" (in English, "Milky"). This management tool helps to recognize several management problems. For recognition of systematic patterns and single unusual testdays, a monthly time-trend analysis was developed to smooth the random fluctuations and display the yearly production pattern. In addition to analyzing single testday deviations from the mean, modeled herd solutions assist users in identifying repeated phenomena and enable the forecasting of the management pattern for the subsequent year. The solutions are displayed either as tables or graphs plotted by calendar months. In addition to management effects of the farmer's own herd, he or she can request country or region percentiles to be displayed in the graphs. The Web service has been offered to farmers and dairy advisors since 2001, and it has proved to be a powerful tool for herd monitoring and planning.

Key words: test-day model, herd management

\section{INTRODUCTION}

The genetic evaluation of production and health traits in dairy cattle has always been economically essential. To enable genetic evaluation, records of produc-

Received August 8, 2006.

Accepted December 21, 2006.

${ }^{1}$ Corresponding author: minna.koivula@mtt.fi tion and SCC as well as pedigree information on cows have been collected widely into national databases. The fitting of genetic models to the collected data is an important way of predicting the breeding values of animals and testing genetic theories. The model used for breeding value estimation depends on the type of records and computing capacity. At the beginning of the 1980 s, only models including breeding values for sires (sire models) were feasible. Since the early 1990s, however, models have been extended to also include the breeding values of cows (animal models). These models initially used 305-d production records. When it became computationally possible to use monthly test-day data in animal models instead of 305-d yields, interest in genetic evaluation using test-day (TD) models increased among dairy breeders (Swalve, 2000; Jensen, 2001).

Growing computing power and the newly developed computing algorithms soon allowed the TD models to become an industry standard in dairy cattle evaluation. For example, in Finland, multiparity random regression TD models were implemented for production traits (milk, protein, and fat yield; Mäntysaari, 1999; Lidauer et al., 2000) and for the SCC (used as $\log _{10}$ cells $/ \mu \mathrm{L}$ ), which indicates udder health (Negussie et al., 2002, 2006).

There are several advantages to using TD models compared with the traditional 305-d lactation model (Swalve, 2000). Individual test-day effects can be included in a TD model, and environmental effects peculiar to each test day can be accounted for. Better modeling of the herd environment improves the accuracy of cow breeding values. Advanced TD models can also account for individual differences in the shape of the lactation curve and allow the breeding value to be obtained for any day of the lactation period. Moreover, instead of herd-year (hy) classification of management groups, the herd-test-day (htd) classification in the TD model allows month-to-month short-term environmental variability in the traits to be accounted for.

Test-day models provide the possibility of using the solutions of the htd effects as a continuous herd-man- 
agement monitoring tool. When breeding values of dairy animals are estimated with the TD model, misinforming effects of systematic environmental factors such as age and season are excluded. This allows additional information to be extracted on a herd level. With a TD model, one test-day result of an individual cow can be presented as a sum of the effect solutions. In the Finnish random regression TD models for production and SCC traits, the fixed effects considered are age at calving, year and month of the test, herd year, and stage of lactation, and for production traits the gestation stage is also included. Furthermore, random effects accounted for are the htd, daily breeding value, and daily nongenetic animal effect (Mäntysaari, 1999; Lidauer et al., 2000; Negussie et al., 2002, 2006). These effects are separately calculated for primi- and multiparous cows. The summing of TD model solutions for the hy and htd effect provides a means to derive an estimate of the monthly herd production level (herd-management level) that is independent of all other above-mentioned effects in the evaluation model. Therefore, all the variation in herd management levels is due to different management practices.

Originally, the use of milk recording was motivated by herd management. Over the years, the yearly cowwise production records have been used extensively. In 1992, Fourdraine et al. published a herd-management microcomputer program that used test-day records to monitor and evaluate herd management. Furthermore, Everett et al. (1994) suggested using results from a within-herd TD model for monitoring management and genetics in dairy cattle. Apart from the latter, other applications in which management solutions from animal evaluation would have been used in herd management have not been described in the literature.

In Finland, monthly herd-management effect solutions from the TD model are provided for authorized users such as farmers and dairy advisors in the herdmanagement Web application "Maitoisa" (in English, "Milky"). The Maitoisa has been in use since 2001 (Nousiainen, 2003). The aim of this report is to describe the Maitoisa program and give a few examples of the use of the application.

\section{MATERIALS AND METHODS}

\section{Solutions for Herd Management}

After summing the hy and htd solutions of the TD models, country means of herd-management levels can be calculated. Each herd will then receive the management levels for milk, protein, and fat yield and SCC, which will be expressed as deviations from the monthly country mean production levels. Values are reported separately for primi- and multiparous cows. The TD model provides management solutions for fat and protein yield $(\mathrm{kg})$, and for clarity these are converted to the fat and protein percentages (\%) of the milk. Fat and protein percentages are calculated with the following equation:

$$
h \hat{t} d_{i \%, j}=100 \times \frac{h \hat{t} d_{i, j}+\bar{y}_{i}}{h \hat{t} d_{m i l k, j}+\bar{y}_{m i l k}}-\overline{h t d}_{i \%}
$$

where $h \hat{t} d_{i \%, j}$ is the predicted solution for herd management level in herd-test-month $j$ for fat percentage or protein percentage; $h \hat{t} d_{i, j}$ is the deviation of the herd fat or protein yield from the country mean herd production year-month level; $\bar{y}_{i}$ is the phenotypic mean of the fat or protein yield; $h \hat{t} d_{m i l k, j}$ is the herd deviation of the milk yield from the country mean herd milk production year-month level; $\bar{y}_{\text {milk }}$ is the phenotypic mean of the milk yield; and $\overline{h t d}_{i \%}$ is the fat or protein percentage of the milk.

Because monthly herd management levels are deviations from the country mean levels, a herd that follows an average seasonal variation has a monthly management level that is a straight line if plotted against years and months. However, if the plotted management levels fluctuate differently from the national level, it is possible to recognize poorer (or better) performance in certain phases of the yearly feeding cycle.

Deviations of herd management levels are further modeled to assist in the identification of unusual test days and repeated phenomena, and in predicting future year-month production. After testing different models for the recognition of seasonal patterns and single unusual test days, a time trend analysis was developed to smooth the random fluctuations and to display the yearly production pattern. This time trend model consists of the linear trend on calendar month within herd feeding year $\left(m t h_{k}\right)$, regressions on 2 yearly repeating sine curves (12-mo amplitude) that have a phase difference of $2 \mathrm{mo}$, and a third regression on the sine function with a 24-mo amplitude. Thus, the covariables are

$$
\begin{aligned}
& s_{12 a}=\sin \left[\frac{2}{12} \pi \times\left(m t h_{k}-6\right)\right] \\
& s_{12 b}=\sin \left[\frac{2}{12} \pi \times\left(m t h_{k}-8\right)\right] \\
& s_{24}=\sin \left[-\frac{2}{6} \pi \times\left(m t h_{k}+6\right)\right]
\end{aligned}
$$

In the final model, 3 sine curves and a monthly linear trend are fitted as fixed effects for each herd and as a random effect within each hy. A test of outliers was 
included in the model to detect test months that are statistically deviant. A management solution was judged to be an outlier if the monthly estimate $\left(h \hat{t} d_{i, j}\right)$ deviated by more than one herd standard deviation $\left[\sigma_{h t d_{i}}(h e r d)\right]$ unit from the value predicted by the time trend model. Different thresholds were tested, and this rather sensitive test was chosen.

\section{Herd Management Tool in Practice}

To use the model, script files that automatically update the database for management levels for new herd solutions and estimate the predicted values according to the time trend model were programmed with SAS (SAS Institute, 1999). A user-friendly Web application (Maitoisa) was then programmed to display the herd management levels and time trend analysis results.

The herd management levels of the milk yield (milk deviation, kilograms/day), protein and fat percentages (protein and fat deviation, \%), and SCC used in Maitoisa help to recognize several management problems. In addition to raw herd-management effects, the modeled deviations in the herd-management level assist users in identifying herd-specific phenomena. These can be strong fluctuations in the modeled graph, or significant departures of the raw management effect solutions from the usual yearly pattern. When the problem has been detected, it can often be connected to general insufficient feeding, seasonal feeding difficulties, and so on. High SCC solutions can reveal either continuous problems with udder health, or if the levels fluctuate, inconsistent and careless udder hygiene. Notable differences between the milk solutions of primi- and multiparous cows will suggest that the management of replacement heifers is unsatisfactory.

The herd management levels are displayed as tables or graphs plotted against calendar months and years, and users can save the results to their own computer. In addition to management effects for their own herds, farmers can request the country or region percentiles to be displayed in the graphs. The percentiles are calculated using SAS Proc Univariate default option 5 (empirical distribution function with averaging). With the help of percentiles, users can compare deviations in their own herd-management levels with the regional level. Such information is useful because it first provides a picture of the performance of a herd from one month to the next, and under suboptimal performance, sends a clear signal and thereby alerts farmers to take appropriate herd-management measures.

To open the service, the user requires a user name and password. On the opening screen, the user first types in the herd number and then selects the cow category (primi- or multiparous cows) and the trait to be displayed in the graph or table. When the task is defined, the system produces the requested information from the database.

\section{RESULTS AND DISCUSSION}

Figure 1 shows a snapshot from a Web browser window that displays management solutions from the MTT Agrifood Research herd hosting the national embryotransfer breeding program in Jokioinen. The graph illustrates the actual monthly SCC solutions for primiparous cows and the corresponding prediction curve. In Figure 1, the prediction curve is extended to year 2007 to show the form of the underlying seasonal variation in the herd. Figures 2A and 2B present the herd-management solutions of milk yield for primi- and multiparous cows in the same herd. The zero level in the graph represents the country mean level. The predicted milk curves follow the observed curves well. Thus, the model provides a reasonable fit to the data. In Figure 3, the milk deviation in multiparous cows and the 5th and 95th percentiles for the milk deviation are presented. From Figures 2 and 3, one can conclude that the embryo-transfer herd is doing much better than herds on average in Finland, and when looking at multiparous cows, most of the time the herd is within the best $5 \%$ in Finland. However, the plot indicates seasonal variation in performance, such as declines in milk production during summer and autumn, which suggests that management of the herd can still be improved. The SCC management solutions in Figure 1 show more variability and more test months flagged as extraordinary than was seen for the production solutions (Figure 2). This is seen in many herds, because the SCC is more affected by unpredictable changes in conditions, outbreaks of infection, and so on.

Because Maitoisa uses the hy and htd solutions from random regression TD models, the results are corrected for lactation stage, calving age and season, parity, and breeding value effects. This means that, in a way, all animals are standardized, as if they were at the same age and lactation stage and had the same breeding values on all test days. Therefore, all the differences between the herd solutions are due to different herdmanagement practices. Positive milk, protein, and fat deviations confirm that the herd management is better than on average, and negative deviations should alert a farmer to make improvements, for example, in feeding. By contrast, a positive SCC deviation may indicate udder health problems. To make reading the SCC figures consistent with the production figures, the vertical axis in the graph has been reversed. Thus, the values at the upper part of the y-axis are desirable and those at the lower part are undesirable. 


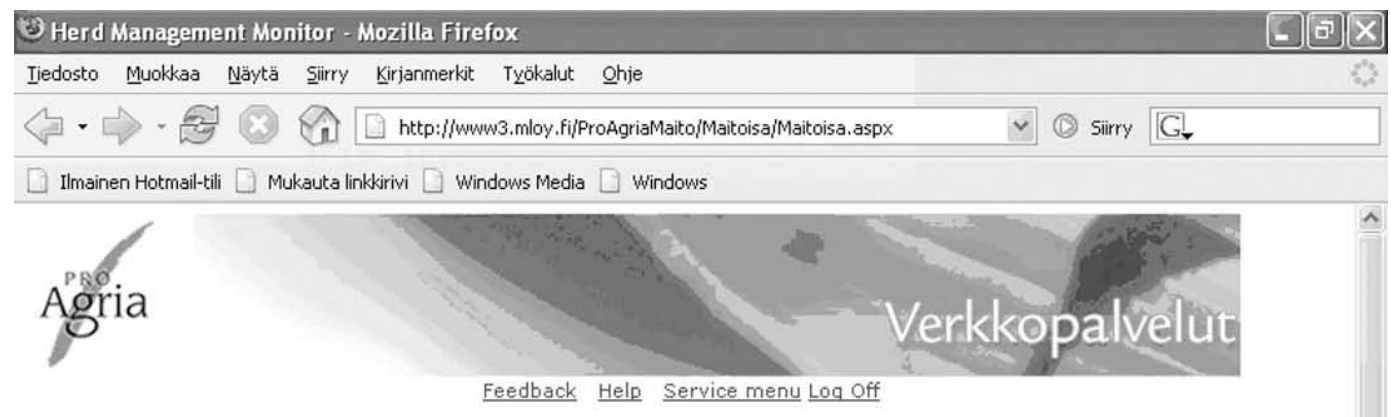

ProAgria Milk Herd Management Monitor

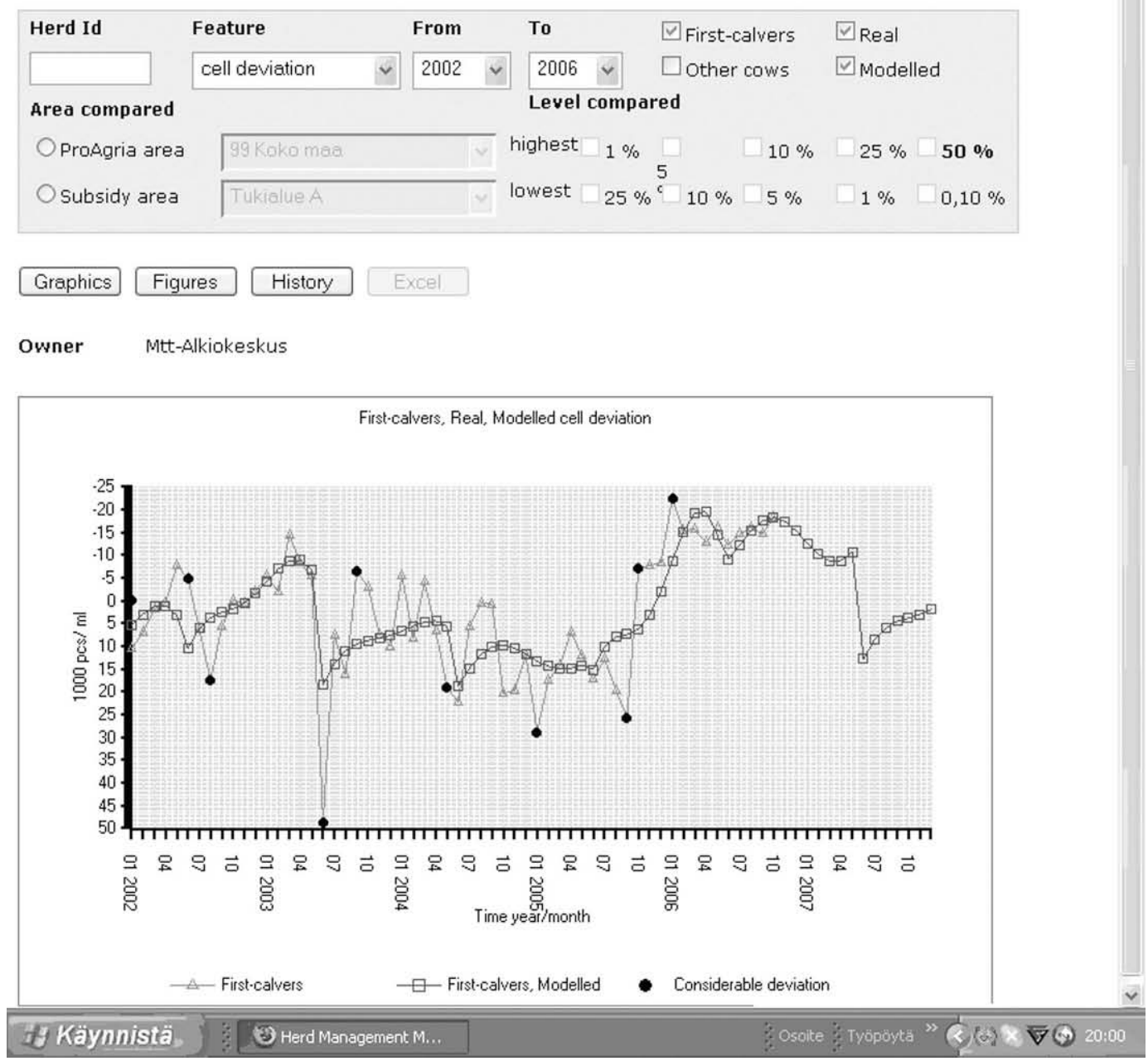

Figure 1. Snapshot from an Internet browser window displaying the dairy herd management application "Maitoisa." The graph presents monthly management effect solutions for SCC of primiparous cows in the MTT research herd.

The TD models are constantly improved to account for more systematic environmental effects. For example, in the Joint Nordic Test-Day model (Lidauer et al., 2006), the variation due to previous days dry and the herdwise lactation persistency are accounted for. This further improves the accuracy of EBV as well as the accuracy of within-herd management effect solutions. It is important to recognize that the herd testmonth solutions are corrected with respect to those systematic effects and that some of those effects (e.g., calving age or season) also can be controlled by a herd manager. 
A
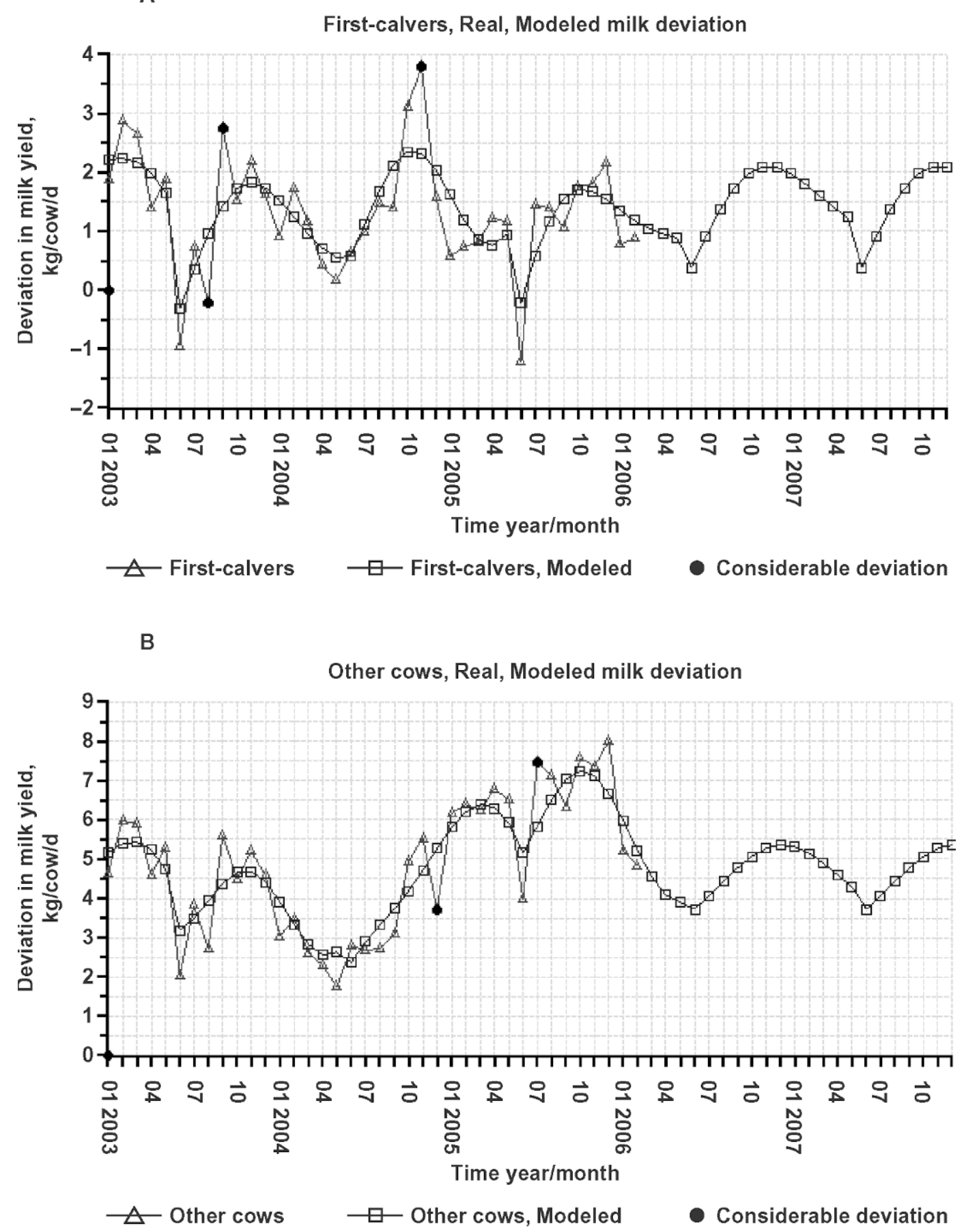

Figure 2. Observed and predicted deviations in herd-management levels of milk yield: A) primiparous cows (first calvers); B) multiparous cows (other cows).

Tools that enable factors affecting production to be recognized provide a means to improve herd management. The herd-management Web tool described in this paper is the result of a long period of development (Kaustell, 1998; Nousiainen, 2003), and it has been in use since 2001. In 2006 the number of visits to the Maitoisa Web site was 6,275, whereas the number of herds in participating in milk recording was 10,004 (J. Kyntäjä, ProAgria Finland, personal communication). Farmers and advisers have considered Maitoisa helpful 


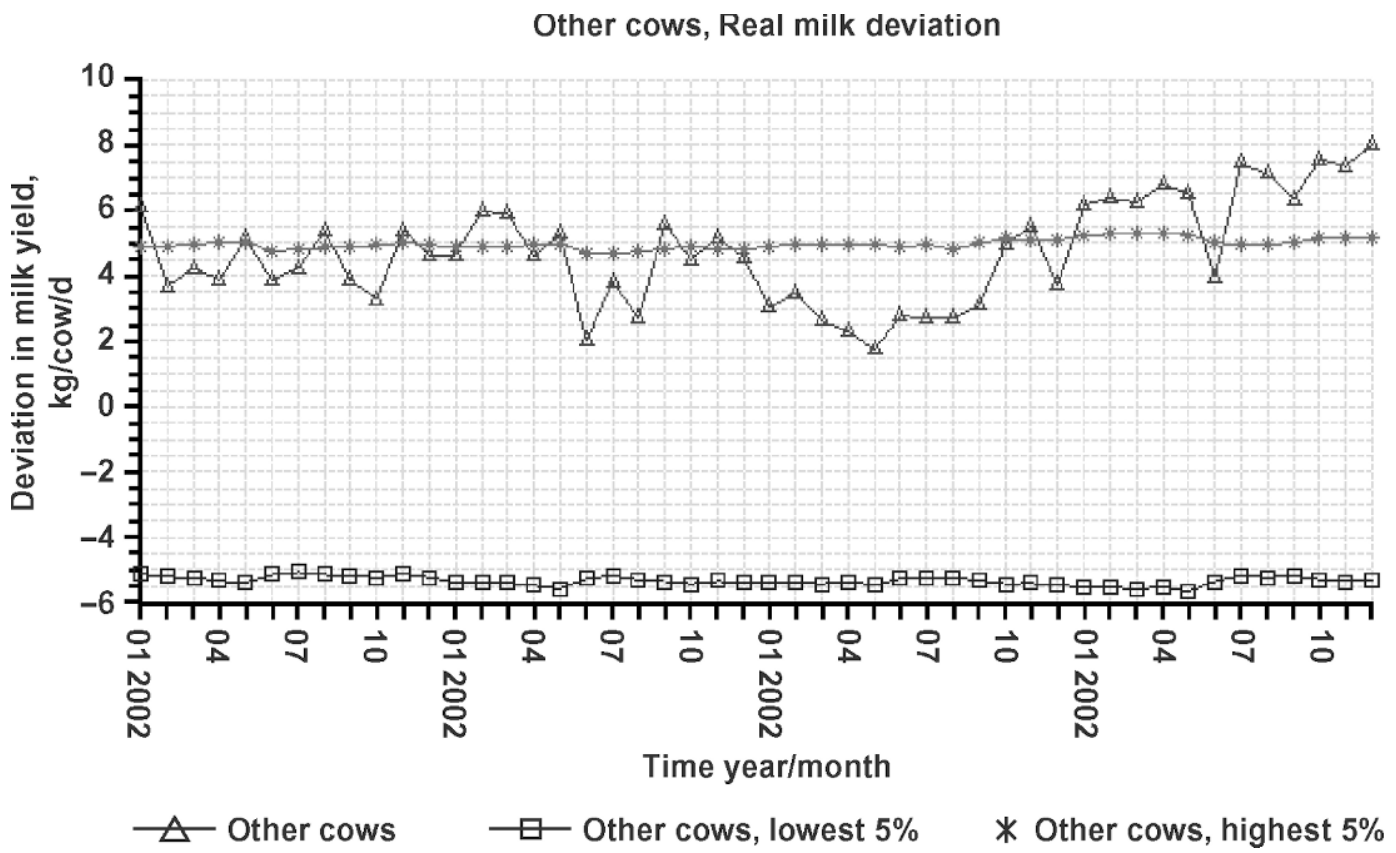

Figure 3. Observed deviations in herd-management level of milk yield in multiparous cows plotted against the 5th and 95th percentiles for deviations in the whole country.

and straightforward to use, and it has proved to be a powerful tool for herd monitoring and planning.

\section{ACKNOWLEDGMENTS}

The equation to convert fat and protein yield htd solutions into percentages was originally described by Martin Lidauer. The Finnish Animal Breeding Association (FABA) and Pro Agria Maatalouden Laskentakeskus Oy (MLOY) are maintaining and providing the service for users. We thank Roy Siddal for revising the language of the manuscript.

\section{REFERENCES}

Everett, R. W., F. Schmidt, and L. H. Wadell. 1994. A test-day model for monitoring management and genetics in dairy cattle. J. Dairy Sci. 77(Suppl. 1):267. (Abstr.)

Fourdraine, R. H., M. A. Tomaszewski, and T. J. Cannon. 1992. A computer program to analyze herd management using DHI test day information. Pages 478-482 in Proc. Int. Symp. on Prospects on Automatic Milking. EAAP Publ. No. 65. Pudoc Scientific Publishers, Wageningen, the Netherlands.

Jensen, J. 2001. Genetic evaluation of dairy cattle using test-day models. J. Dairy Sci. 84:2803-2812.

Kaustell, K. 1998. Karjantarkkailun koelypsytulosten hyödyntäminen lypsykarjatilan päätösten teossa. Kotieläintieteen Päivät, 26.-27.5.1998, Helsinki, Finland.
Lidauer, M., E. Mäntysaari, I. Stranden, and J. Pösö. 2000. Multipletrait random regression test-day model for all lactations. Interbull Bull. 25:81-84.

Lidauer, M., J. Pedersen, J. Pösö, E. A. Mäntysaari, I. Strandén, P. Madsen, U. S. Nielsen, K. Johansson, J.-A. Eriksson, and G. P. Aamand. 2006. Joint Nordic test day model: Evaluation model. Interbull Bull. 35:103-107.

Mäntysaari, E. A. 1999. Derivation of multiple trait reduced rank random regression $(\mathrm{RR})$ model for the first lactation test day records of milk, protein and fat. Page 2 in Proc. 50th Annu. Mtg. Eur. Assoc. Anim. Prod., Zurich, Switzerland. Wageningen Pers, Wageningen, the Netherlands.

Negussie, E., M. Koivula, and E. A. Mäntysaari. 2002. Random regression test-day model for genetic evaluation of Finnish dairy cattle for somatic cell count (SCC). Page 39 in Proc. 53rd Annu. Mtg. Eur Assoc. Anim. Prod., Cairo, Egypt. Wageningen Pers, Wageningen, the Netherlands.

Negussie, E., M. Koivula, E. A. Mäntysaari, and M. Lidauer. 2006. Genetic evaluation of somatic cell score in dairy cattle considering first and later lactations as two different but correlated traits. J. Anim. Breed. Genet. 123:224-238.

Nousiainen, J. 2003. The use of monthly herd solutions of the test day model in dairy herd management in the "Maitoisa" internet application. Page 145 in Proc. NJF's 22nd Congr. "Nordic Agriculture in Global Perspective," Turku, Finland. Tampere University Print, Tampere, Finland.

SAS Institute. 1999. Base SAS Software. Version 8. SAS Inst. Inc., Cary NC.

Swalve, H. H. 2000. Theoretical basis and computational methods for different test-day genetic evaluation methods. J. Dairy Sci. 83:1115-1124. 